Wydziat Nauk Ekonomicznych i Zarzadzania UMK

Katedra Ekonomii

Adam P. Balcerzak

\title{
ROLA TECHNOLOGII TELEINFORMATYCZNYCH W PODNOSZENIU MIKRO ORAZ MAKROEKONOMICZNEJ EFEKTYWNOŚCI GOSPODARKI
}

Z a ry s treś c i. W artykule przeanalizowany został wpływ proliferacji technologii teleinformatycznych na efektywność gospodarczą. Celem artykułu jest odpowiedz na pytanie, jakie czynniki muszą być spełnione, aby w danej gospodarce było możliwe szerokie wykorzystanie potencjału tych technologii?

Słow a kluc zow e : innowacyjność, Internet, teleinformatyka, technologia ogólnego zastosowania.

\section{WPROWADZENIE}

Obecnie powszechnie przyjmuje się tezę, zgodnie z którą rozwój i dyfuzja technologii teleinformatycznych stanowi jedną z fundamentalnych sił napędowych transformacji krajów wysoko rozwiniętych. Jest on także jednym z ważniejszych czynników wpływających na powstanie nowej globalnej gospodarki. W celu wykazania słuszności takiej perspektywy niezbędne jest rozstrzygnięcie trzech kwestii. Po pierwsze, konieczne jest wskazanie mechanizmu, w wyniku którego rozwój technologii teleinformatycznych będzie się przekładał na lepsze wyniki mikro oraz makroekonomiczne poszczególnych gospodarek. Drugą z nich jest wykazanie uniwersalności zjawiska wzrostu znaczenia tych technologii w odniesieniu do większości krajów wysoko rozwiniętych. Trzecią, nie mniej 
ważną kwestią jest wykazanie, w jaki sposób technologie teleinformatyczne mogą prowadzić do znaczącej transformacji współczesnego światowego systemu gospodarczego.

Niniejszy artykuł stanowi próbę odniesienia się do powyższych kwestii. Oprócz tego celem tego opracowania jest odpowiedź na pytanie, jakie czynniki muszą być spełnione, aby w danej gospodarce było możliwe szerokie wykorzystanie potencjału technologii teleinformatycznych?

\section{MAKROEKONOMICZNE KONSEKWENCJE PROLIFERACJI TECHNOLOGII TELEINFORMATYCZNYCH}

$\mathrm{Na}$ podstawie literatury poświęconej wpływowi technologii teleinformatycznych na wyniki makroekonomiczne można mówić o dwóch bezpośrednich kanałach, jakimi rozwój tych technologii może się przekładać na wyższe tempo wzrostu gospodarczego. Oprócz tego przyjmuje się, że teleinformatyka spełnia kryteria stawiane technologiom ogólnego zastosowania, dzięki czemu przynosi pośrednie długookresowe korzyści ekonomiczne związane z proliferacją fundamentalnych innowacji tej kategorii.

Pierwsze dwa kanały związane $\mathrm{z}$ bezpośrednim wpływem technologii teleinformatycznych na podniesienie tempa wzrostu gospodarczego zostały przedstawione na rysunku 1. Podstawowym, a zarazem najłatwiejszym do zweryfikowania empirycznego jest pozytywny wpływ wzrostu efektywności w samej branży teleinformatycznej, co w zależności od udziału tej branży w PKB będzie się bezpośrednio przekładać na wyższe wyniki gospodarcze ${ }^{1}$. Ponadto jeżeli w branży teleinformatycznej korzyści ekonomiczne związane z postępem technologicznym będą wykraczały poza korzyści przechwytywane przez poszczególnych inwestorów oraz właścicieli, będzie to oznaczało pojawienie się efektów sieciowych oraz pozytywnych efektów zewnętrznych, co przekłada się na wzrost ogólnej produktywności czynników produkcji (MFP).

${ }^{1}$ Mimo relatywnie małego udziału branży teleinformatycznej w PKB większości krajów, według badań empirycznych kanał ten może być źródłem istotnego wzrostu produktywności pracy w skali makro. 


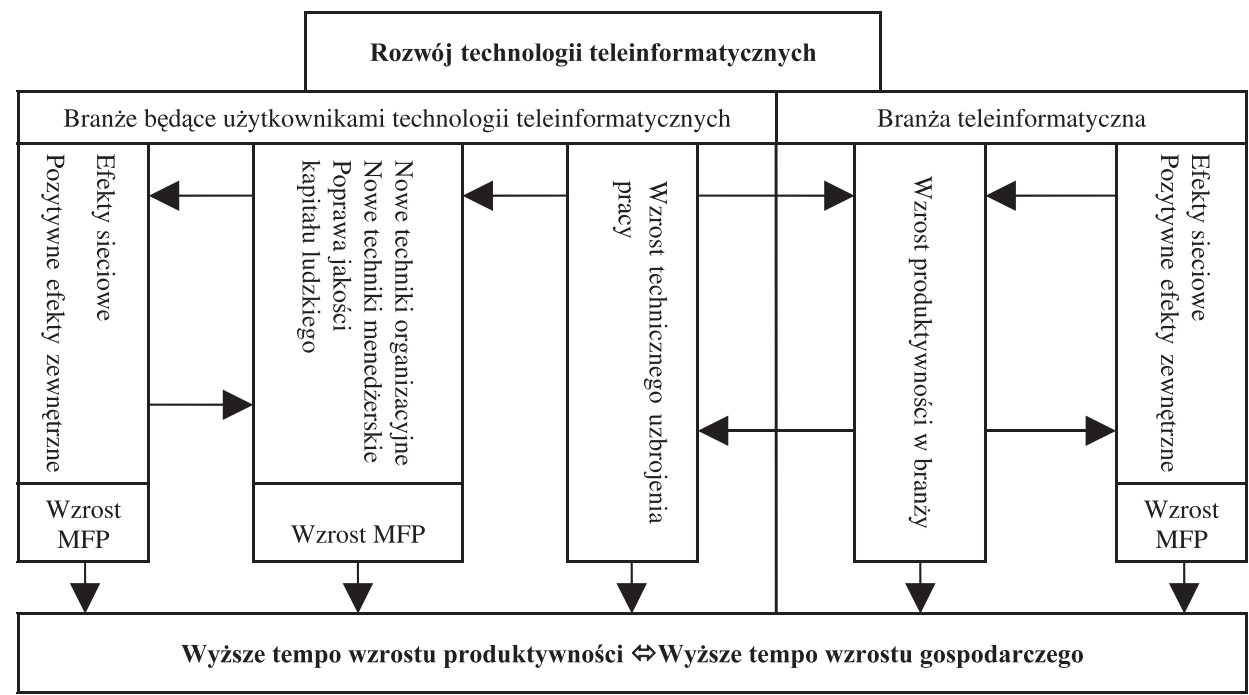

Rys 1. Wpływ technologii teleinformatycznych na wyższe tempo wzrostu produktywności oraz wzrost gospodarczy

MFP - ogólna produktywność czynników produkcji tożsama z resztą Solowa.

Źródło: opracowanie własne na podstawie: Gilbert Cette, Jacques Mairesse, Yousuf Kocoglu (2004), Francisco Daveri (2003, s. 102-125).

Jednakże aby można było mówić o znaczących korzyściach makroekonomicznych wynikających z rozwoju technologii teleinformatycznych, znacznie ważniejsze od korzyści generowanych przez samą branżę teleinformatyczną, są korzyści ekonomiczne osiągane przez branże będące użytkownikami technologii teleinformatycznych. Nakłady na inwestycje w technologie teleinformatyczne ponoszone przez poszczególne przedsiębiorstwa mogą prowadzić do tradycyjnych korzyści związanych ze wzrostem technicznego uzbrojenia pracy, co przekłada się na wyższą produktywność. Ponadto inwestycje w technologie teleinformatyczne stanowią czynnik umożliwiający wprowadzanie nowych rozwiązań organizacyjnych, procesowych oraz produktowych, mogą sprzyjać lepszemu wykorzystaniu i podniesieniu jakości kapitału ludzkiego. Także w tym wypadku w sprzyjających warunkach mogą się pojawić pozytywne efekty zewnętrze oraz efekty sieciowe, które nie są przechwytywane przez poszczególne podmioty gospodarcze, a które kumulatywnie przekładają się na wzrost dobrobytu społecznego ${ }^{2}$. Pojawienie się tych wszystkich makroekonomicznych korzyści jest w znacznej mierze uzależnione od efektywnego sytemu instytucjonalnego, który

$2 \mathrm{~W}$ przypadku tych ostatnich jednym z większych problemów stanowi kwestia mierzenia tych efektów i uchwycenia ich przez powszechnie stosowane metody ilościowe. 
będzie sprzyjał wykorzystywaniu najmowych rozwiązań teleinformatycznych przez mikropodmioty. Do najważniejszych elementów tego sytemu należy wysoka elastyczność gospodarki oraz efektywna regulacja gospodarcza sprzyjająca wysokiej presji konkurencyjnej.

W tabeli 1 . zostały zebrane badania empiryczne o charakterze mikroekonomicznym obejmujące swym zasięgiem ostatnie dwie dekady, w których analizowano związki między inwestycjami w technologie teleinformatyczne a wzrostem produktywności oraz uwarunkowania, jakie muszą być spełnione, aby było możliwe podniesienie produktywności przedsiębiorstw w konsekwencji zastosowania takich technologii. $\mathrm{Z}$ badań tych wynika, że największe korzyści związane $\mathrm{z}$ inwestycjami w technologie teleinformatyczne przekładające się na wyższą produktywność można odnieść, gdy tym nakładom towarzyszą inwestycje w komplementarne niematerialne zasoby organizacyjne takie, jak:

Tabela 1. Badania poświęcone wpływowi technologii teleinformatycznych na podniesienie produktywności i mikropodmiotów

\begin{tabular}{|c|c|c|c|}
\hline Autorzy badania & $\begin{array}{l}\text { Próba badawcza } \\
\text { oraz okres } \\
\text { badania } \\
\end{array}$ & Problem badawczy & Wyniki \\
\hline $\begin{array}{l}\text { Nick Bloom, } \\
\text { Raffaella Sadun, } \\
\text { John Van } \\
\text { Reenen (2007) }\end{array}$ & $\begin{array}{l}\text { Międzynarodowe } \\
\text { korporacje } \\
\text { amerykańskie oraz } \\
\text { nieamerykańskie } \\
\text { funkcjonujące } \\
\text { w Wielkiej Brytanii }\end{array}$ & $\begin{array}{l}\text { Czy wyższa efektywność } \\
\text { przedsiębiorstw ame- } \\
\text { rykańskich w wykorzy- } \\
\text { staniu inwestycji w ICT } \\
\text { niż przedsiębiorstw } \\
\text { europejskich wynika tylko } \\
\text { z ulokowania w USA? } \\
\end{array}$ & $\begin{array}{l}\text { Korporacje amerykańskie funkcjonujące } \\
\text { w Wielkiej Brytanii uzyskują wyższą } \\
\text { produktywność związaną z inwestycjami } \\
\text { w ICT niż korporacje nieamerykańskie } \\
\text { w wyniku stosowania rozwiązań } \\
\text { organizacyjnych sprzyjających lepszemu } \\
\text { wykorzystaniu ich potencjału. }\end{array}$ \\
\hline $\begin{array}{l}\text { Sandra Black, } \\
\text { Lisa Lynch } \\
\text { (2004 a, } \\
\text { s. 97-116; 2001, } \\
\text { s. 434-445) }\end{array}$ & $\begin{array}{l}\text { Reprezentacyjna } \\
\text { próba dla firm } \\
\text { amerykańskich, } \\
\text { lata 1993-1997; } \\
\text { lata 1987-1993 }\end{array}$ & $\begin{array}{l}\text { Wpływ praktyk pracy, } \\
\text { inwestycji w ICT } \\
\text { oraz kapitał ludzki } \\
\text { na produktywność }\end{array}$ & $\begin{array}{l}\text { Firmy, w których pracownicy } \\
\text { na stanowiskach niemenedżerskich } \\
\text { legitymują się wyższym wykształceniem, } \\
\text { wykorzystują większą ilość ICT oraz } \\
\text { gdzie wprowadzane są nowe techniki } \\
\text { pracy, osiągają wyższą produktywność. }\end{array}$ \\
\hline $\begin{array}{l}\text { Erik } \\
\text { Brynjolfsson, } \\
\text { Lorin Hitt (2003, } \\
\text { s. 793-808) }\end{array}$ & $\begin{array}{l}527 \text { dużych } \\
\text { amerykańskich } \\
\text { przedsiębiorstw, } \\
\text { lata 1987-1994 }\end{array}$ & $\begin{array}{l}\text { Wpływ komputeryzacji } \\
\text { na produktywność } \\
\text { przedsiębiorstw }\end{array}$ & $\begin{array}{l}\text { Wysoki pozytywny wpływ na produktyw- } \\
\text { ność przedsiębiorstw w długim okresie, } \\
\text { pięciokrotnie przekraczający korzyści } \\
\text { krótkookresowe, których osiągnięcie } \\
\text { wiązało się z koniecznością ponoszenia } \\
\text { znacznych nakładów w zakresie niena- } \\
\text { macalnego kapitału organizacyjnego. }\end{array}$ \\
\hline $\begin{array}{l}\text { Timothy } \\
\text { Bresnahan, Erik } \\
\text { Bynjolfsson, } \\
\text { Lorin Hit (2002, } \\
\text { s. 339-376] }\end{array}$ & $\begin{array}{l}300 \text { dużych } \\
\text { amerykańskich } \\
\text { przedsiębiorstw, } \\
\text { lata 1987-1996 }\end{array}$ & $\begin{array}{l}\text { Powiązania pomiędzy } \\
\text { inwestycjami w ICT, ja- } \\
\text { kością kapitału ludzkiego } \\
\text { oraz decentralizacją } \\
\text { struktur organizacyjnych }\end{array}$ & $\begin{array}{l}\text { Inwestycje w ICT w powiązaniu ze zmia- } \\
\text { nami praktyk pracy, poprawą jakości } \\
\text { kapitału ludzkiego, decentralizacją pro- } \\
\text { cesu decyzyjnego prowadzą do wyższej } \\
\text { produktywności przedsiębiorstw. }\end{array}$ \\
\hline
\end{tabular}

Źródło: opracowanie własne. 
nowe procesy biznesowe, zdecentralizowane i bardziej elastyczne struktury organizacyjne, wyższa jakość kapitału ludzkiego, nowe strategie. Badania te potwierdzają tezę, zgodnie z którą wzrost produktywności związany z inwestycjami w teleinformatykę nie jest automatyczny, a efektywne wykorzystanie nowych rozwiązań teleinformatycznych wymaga znaczących strukturalnych dostosowań mikropodmiotów.

Badania wskazujące na związek między dyfuzją technologii teleinformatycznych a wyższą efektywnością makroekonomiczną poszczególnych gospodarek zostały zebrane w tabeli 2 . Zestawienie to potwierdza, że podobnie jak w przypadku perspektywy mikroekonomicznej korzyści te nie mają automatycznego charakteru. Samo istnienie znacznego sektora teleinformatycznego w danym kraju, czy też ogólnie wysoki poziom zaawansowania technologicznego danego kraju nie gwarantuje istotnego wpływu teleinformatyki na przyspieszenie tempa wzrostu produktywności w skali makroekonomicznej. Dopiero szeroka dyfuzja tych technologii w branżach będących użytkownikami technologii teleinformatycznych oraz powszechna restrukturyzacja tych branż zgodna z logiką nowej

Tabela 2. Wpływ technologii teleinformatycznych na produktywność w ujęciu makroekonomicznym

\begin{tabular}{|c|c|c|c|}
\hline Autorzy & $\begin{array}{c}\begin{array}{c}\text { Kraje i okres } \\
\text { badania }\end{array} \\
\end{array}$ & Problem badawczy & Wyniki \\
\hline $\begin{array}{l}\text { Bart Van } \\
\text { Ark, Robert } \\
\text { Inklaar } \\
\text { i Robert } \\
\text { Mcguickin } \\
(2003, \\
\text { s. 56-63) }\end{array}$ & $\begin{array}{l}\text { USA, Kanada } \\
\text { i Unia } \\
\text { Europejska, } \\
\text { lata 90. XX } \\
\text { wieku }\end{array}$ & $\begin{array}{l}\text { Wpływ branż ICT } \\
\text { oraz branż będących } \\
\text { ich intensywnymi } \\
\text { użytkownikami } \\
\text { na produktywność }\end{array}$ & $\begin{array}{l}\text { Europa osiągnęła najsłabsze wyniki, w szczegól- } \\
\text { ności w zakresie poprawy produktywności w bran- } \\
\text { żach będących użytkownikami ICT. Powodem } \\
\text { tego był restrykcyjny system regulacji opóźniający } \\
\text { proliferację ICT i tempo zmian technologiczno- } \\
\text { organizacyjnych niezbędne dla wykorzystania ich } \\
\text { potencjału. }\end{array}$ \\
\hline \begin{tabular}{|l|} 
Dominic \\
Salvatore \\
(2003b, \\
s. 531-540)
\end{tabular} & \begin{tabular}{|l|} 
Kraje G7, lata \\
90. XX wieku
\end{tabular} & $\begin{array}{l}\text { Analiza źródeł sukcesu } \\
\text { USA w wykorzystaniu } \\
\text { potencjału ICT oraz nowej } \\
\text { gospodarki porównaniu } \\
\text { z pozostałymi krajami } \\
\text { z grupy G-7 w latach } 90 .\end{array}$ & $\begin{array}{l}\text { Źródło przewagi USA - system instytucjonalny } \\
\text { sprzyjający wykorzystaniu potencjału nowej gospo- } \\
\text { darki, którego elementami były bardzo elastyczny } \\
\text { rynek pracy, bardzo rozwinięty rynek finansowy, } \\
\text { wysoki poziom konkurencji, co przekładało się } \\
\text { na wysoką elastyczność makroekonomiczną go- } \\
\text { spodarki i wyższe tempo wzrostu potencjalnego } \\
\text { PKB niż w pozostałych krajach grypy G-7. }\end{array}$ \\
\hline $\begin{array}{l}\text { Surendra } \\
\text { Gera, } \\
\text { Wulong } \\
\text { Gu, Frank } \\
\text { Lee (1999, } \\
\text { s. 384-407) }\end{array}$ & $\begin{array}{l}\text { Kanada } \\
\text { i USA, } \\
1971-1993\end{array}$ & $\begin{array}{l}\text { Związek między inwesty- } \\
\text { cjami w ICT a wzrostem } \\
\text { produktywności pracy } \\
\text { oraz rozmiar efektów } \\
\text { przenikania związanych } \\
\text { z inwestycjami R\&D } \\
\text { w branży teleinforma- } \\
\text { tycznej }\end{array}$ & $\begin{array}{l}\text { Zarówno w Kanadzie, jak i w USA inwestycje } \\
\text { w ICT oraz pozytywne efekty zewnętrzne związane } \\
\text { z R\&D w branży ICT są znaczące. Stopa zwrotu } \\
\text { z inwestycji jest wysoka i wynosi około } 30 \% \\
\text { rocznie. }\end{array}$ \\
\hline
\end{tabular}

Źródło: opracowanie własne. 
technologii przekłada się wyższą produktywność makroekonomiczną. Badania te potwierdzają także, że tempo tego procesu jest silnie uzależnione od kształtu systemu instytucjonalnego oraz efektywnej polityki państwa sprzyjającej podnoszeniu innowacyjności gospodarki.

W ostatnich latach pojawia się także coraz więcej argumentów na rzecz tezy, iż nie można traktować technologii teleinformatycznych jedynie jako zwykłych inwestycji technologicznych przynoszących tylko bezpośrednie krótko i średniookresowe korzyści będące źródłem wzrostu produktywności. Technologie teleinformatyczne stanowią technologie ogólnego zastosowania (general purpose technologies), które są najważniejszym źródłem długookresowego wzrostu gospodarczego (Brynjolfsson, Hitt, 2003, s. 805; Carlsson, 2004, s. 245-264).

Technologie ogólnego zastosowania charakteryzuje wysoki dynamizm wynikający z potencjału do zastosowania w wielu sektorach gospodarki. Przekłada się to na wzrost efektywności całej gospodarki i generuje przyspieszenie wzrostu produktywności na poziomie makroekonomicznym w długim okresie. Ważną cechą technologii ogólnego zastosowania jest to, że są one platformą otwierającą nowe możliwości w wielu dziedzinach, nie stanowią natomiast kompletnych, zamkniętych finalnych rozwiązań. Wykorzystanie potencjału technologii ogólnego zastosowania $\mathrm{z}$ jednej strony wymaga rozwoju i dyfuzji innowacji komplementarnych, z drugiej strony jest czynnikiem determinującym tempo postępu technologicznego w sektorach generujących te innowacje oraz szybkość ich dyfuzji. Oznacza to, że produktywność nakładów poniesionych na rozwój technologii komplementarnych podnosi się w konsekwencji postępu osiagniętego w sektorze wytwarzającego technologię ogólnego zastosowania. Tym samym pojawiają się sprzężenie zwrotne, efekty przenikania, pozytywne efekty sieciowe, które prowadzą do pojawiania się rosnących efektów skali, będących głównym źródłem długookresowego przyspieszenia wzrostu gospodarczego (Bresnahan, Trajtenberg, 1995, s. 84) .

W przypadku pojawienia się nowej generacji technologii spełniającej kryteria technologii ogólnego zastosowania kluczową kwestią z perspektywy wykorzystania jej potencjału gospodarczego jest problem adekwatności systemu

3 Historycy rozwoju gospodarczego do wcześniejszych technologie ogólnego zastosowania będących źródłem największego przyspieszenia wzrostu gospodarczego zaliczają np. maszynę parową, fabryczny system organizacji pracy, dynamo elektryczne. Jednak jak wskazuje wielu ekonomistów w odróżnieniu od tych wcześniejszych technologii ogólnego zastosowania, teleinformatyk jest kluczowym czynnikiem w procesie kreacji, dystrybucji i absorpcji wiedzy, która obecnie stanowi kluczową determinantę podnoszenia dobrobytu społecznego w krajach wysoko rozwiniętych. Czynnik ten może powodować, że technologie teleinformatyczne będą miały jeszcze bardziej doniosłe znaczenie dla praktyki gospodarczej i teorii ekonomii niż pojawienie się tych wcześniej wymienionych technologii ogólnego zastosowania (Engelbrecht, 2005, s. 319). 
instytucjonalnego do nowych realiów technologicznych. W tym kontekście należy podkreślić, że badania ekonomistów związanych z nową ekonomią instytucjonalną dostarczają silnych dowodów wskazujących na stosunkowo niską dynamikę modernizacji systemu instytucji (Williamson, 2000, s. 595-613). Oznacza to, że instytucje zazwyczaj charakteryzują się znacznie wyższą inercją niż technologie ogólnego zastosowania. Tym samym, pojawienie się i rozpowszechnienie nowej technologii ogólnego zastosowania, która może być źródłem przyspieszonego wzrostu gospodarczego, może się odbywać w warunkach instytucjonalnych wypracowanych w okresie dominacji technologii poprzednich generacji. Prowadzi to do sytuacji, w której gospodarka ,utknęła” z systemem instytucjonalnym nieadekwatnym do nowych realiów technologicznych, co musi negatywnie wpływać na wykorzystanie potencjału generowanego przez nową technologię (Eliasson i inni, 2004, s. 289-314; Bresnahan, Trajtenberg, 1995, s. 104). W tych warunkach rośnie znaczenie polityki rządu w kreowaniu efektywnego ładu instytucjonalnego.

Potwierdzają to przytoczone już wyniki badań empirycznych zebrane w syntetycznej formie w tabeli 1 . oraz w szczególności w tabeli 2 . Tym samym dostarczają one także silnych argumentów na rzecz ujęcia traktującego teleinformatykę jako technologię ogólnego zastosowania, która w warunkach efektywnego systemu instytucjonalnego jest źródłem wyższego poziomu produktywności w dłuższym horyzoncie czasowym, jednak urzeczywistnienie tych korzyści może wiązać się ze znacznymi opóźnieniami czasowymi ze względu na konieczne dostosowania strukturalne.

\section{INTERNET JAKO SZCZEGÓLNY PRZYPADEK TECHNOLOGII OGÓLNEGO ZASTOSOWANIA}

Szczególnym przypadkiem technologii ogólnego zastosowania jest rozwój sieci Internet, który w wyjątkowy sposób zwiększa potencjał technologii teleinformatycznych ${ }^{4}$. Przy względnie niskich kosztach Internet umożliwia połączenie istniejących zasobów kapitałowych zakorzenionych w infrastrukturze komputerowej oraz telekomunikacyjnej w otwartą sieć, która w sposób znaczący zwiększa ich użyteczność (OECD, 2004a). W związku z tym należy rozważyć, w jaki

${ }^{4}$ Grzegorz Kołodko podsumował to w następujący obrazowy sposób: „Internet ma podobne znaczenie dla rozwoju gospodarczego na tym etapie cywilizacji jak odkrycie Ameryki pięć wieków temu, ponieważ dodaje do dotychczasowego wymiaru «starego świata» relatywnie jeszcze więcej nowej przestrzeni ekonomicznej, na której można czytać i pisać, uczyć się i wykładać, badać i wdrażać, inwestować i czerpać zyski, produkować i świadczyć usługi, sprzedawać i kupować, magazynować i konsumować” (Kołodko, 2001, s. 14-15). 
sposób teleinformatyka bazująca na infrastrukturze internetowej może się przyczyniać do akceleracji tempa transformacji współczesnych najbardziej rozwiniętych gospodarek.

Bardzo często przytaczaną ekonomiczną korzyścią związaną z rozwojem sieci Internet jest jej potencjał w zakresie ograniczania tradycyjnej asymetrii informacji ${ }^{5}$. Wraz z powstaniem i rozprzestrzenianiem się Internetu uczestnikom gry rynkowej zarówno po stronie popytu, jak i podaży znacznie łatwiej porównywać ceny, następuje wyeliminowanie pośredników, co prowadzi do obniżki kosztów transakcyjnych i może skutkować ograniczeniem barier wejścia na poszczególne rynki (Litan, Rivlin, 2001, s. 314-315) . Elementy te ograniczają tradycyjny zakres wpływu producentów na kształtowanie cen ${ }^{7}$. Prowadzi to do zwiększenia intensywności konkurencyjnej oraz stwarza ciagłą presję na obniżkę kosztów. Największy potencjał dla obniżki kosztów transakcyjnych, związany z powstaniem Internetu, odnotowują branże, których istotą jest przetwarzanie dużej ilości informacji, a w przypadku których tradycyjna informacja przechowywana w formie papierowej może ulec digitalizacji. Do najczęściej przytaczanych przykładów branż odnoszących takie korzyści można zaliczyć obsługę informacyjną ochrony zdrowia, szeroko pojmowane usługi finansowo-ubezpieczeniowe oraz funkcjonowanie aparatu administracyjno-rządowego. Jest to o tyle istotne, że współczesna gospodarka światowa jest coraz bardziej uzależniona od takich informacyjno chłonnych branż. W tabeli 3. zebrano badania empiryczne poświęcone wpływowi rozwoju Internetu oraz handlu elektronicznego na efektywność ekonomiczną przedsiębiorstw.

5 Oczywiście należy pamiętać, że część komentatorów wskazuje także na znaczne zwiększenie tzw. szumu informacyjnego wynikającego z rozwoju Internetu. Można jednak przyjąć, że problem ten może być obecnie efektywnie rozwiązywany w wyniku zastosowania narzędzi pozwalających na ukierunkowaną selekcję informacji.

${ }^{6}$ Oczywiście proces ten nie ma charakteru automatycznego, co dotyczy w szczególności branż, w których dużą rolę odgrywają efekty skali, jak to jest w przypadku wielu branż tzw. tradycyjnej gospodarki, ale także w przypadku sektorów informacyjnych, które często funkcjonują z zasadami typowymi dla monopoli naturalnych.

7 Jednostronne i uproszczone uwzględnianie tej kwestii stało się jednym z powodów powstania bąbla spekulacyjnego na rynku finansowym w branży nowych technologii. Pod koniec XX wieku większość analityków finansowych i inwestorów dostrzegało możliwości Internetu w ograniczaniu kosztów transakcyjnych i eliminowaniu barier wejścia, co jednoznacznie utożsamiali z potencjałem ekspansji nowych firm. Jednocześnie często zapominano, że stanowi to także źródło wzrastającej presji konkurencyjnej, która może eliminować nadzwyczajne zyski mikropodmiotów, tym samym podważać ich wysokie wyceny giełdowe. 
Tabela 3. Wpływ Internetu i handlu internetowego na wzrost efektywności przedsiębiorstw oraz gospodarki w ujęciu makroekonomicznym

\begin{tabular}{|c|c|c|}
\hline Autorzy badania & $\begin{array}{l}\text { Główne } \\
\text { zastosowanie } \\
\text { Internetu }\end{array}$ & Wnioski z badań \\
\hline $\begin{array}{l}\text { Caroline Freud, } \\
\text { Diana Weinhold } \\
(2002, \text { s. 236-240) }\end{array}$ & $\begin{array}{l}\text { Wpływ Internetu } \\
\text { na intensywność } \\
\text { handlu międzyna- } \\
\text { rodowego }\end{array}$ & $\begin{array}{l}\text { Rozwój Internetu był głównym źródłem przyspieszonego ekspor- } \\
\text { tu usług do Stanów Zjednoczonych. Wzrost penetracji Internetu } \\
\text { zagranicą o } 10 \% \text { prowadzi do wzrostu importu usług przez USA } \\
\text { o 1,2\%. Wzrost handlu międzynarodowego na podstawie infra- } \\
\text { struktury internetowej sprzyja lepszej alokacji zasobów i stwarza } \\
\text { bodźce dla wyższej efektywności podmiotów }\end{array}$ \\
\hline $\begin{array}{l}\text { Bruce Kogut, } \\
\text { Anca Metru (2001, } \\
\text { s. 248-264) }\end{array}$ & $\begin{array}{l}\text { Internet jako infra- } \\
\text { struktura rozwoju } \\
\text { systemu wytwa- } \\
\text { rzania i dystrybucji } \\
\text { oprogramowania } \\
\text { open-source } \\
\end{array}$ & $\begin{array}{l}\text { Internet umożliwił powstanie nowego modelu wytwarzania pro- } \\
\text { duktów ICT gwarantującego powstanie endogenicznego mecha- } \\
\text { nizmu innowacyjności eliminującego nieefektywności związane } \\
\text { z istnieniem restrykcyjnych systemów ochrony praw własności } \\
\text { intelektualnej oraz stwarzającego szansę dla krajów rozwijających } \\
\text { się do dołączenia wyścigu w zakresie innowacyjności ICT. }\end{array}$ \\
\hline $\begin{array}{l}\text { William Wilhelm } \\
\text { (2001, s. 235-246); } \\
\text { Brad Barber, } \\
\text { Terrance Odean } \\
\text { (2001, s. 41-54) }\end{array}$ & $\begin{array}{l}\text { Wpływ Internetu } \\
\text { na strukturę ryn- } \\
\text { ków finansowych }\end{array}$ & $\begin{array}{l}\text { Internet jest czynnikiem przyspieszającym ewolucję rynków } \\
\text { finansowych na linii inwestor-instytucja finansowa, sprzyjającym } \\
\text { powstawaniu innowacji produktywnych i organizacyjnych. }\end{array}$ \\
\hline $\begin{array}{l}\text { Severin } \\
\text { Borenstein, Garth } \\
\text { Saloner (2001, } \\
\text { s. 3-12); Dawid } \\
\text { Lucking-Reiley, } \\
\text { Daniel Spulber } \\
\text { (2001, s. 55-68] }\end{array}$ & \begin{tabular}{l|} 
Mikro- oraz ma- \\
kroekonomiczne \\
konsekwencje han- \\
dlu internetowego \\
(e-commerce) za- \\
równo w segmen- \\
cie B2B i B2C
\end{tabular} & $\begin{array}{l}\text { Konsekwencje mikro: wpływ Internetu na istotną obniżkę kosztów } \\
\text { transakcyjnych w szczególności do produktów ulegających łatwej } \\
\text { digitalizacji, obniżkę kosztów pozyskania informacji, wzrost presji } \\
\text { konkurencyjnej, ograniczenie barier wejścia. } \\
\text { Konsekwencje makro: Internet jako czynnik przyspieszający ewo- } \\
\text { lucję rynków pracy, nowe źródło popytu konsumpcyjnego oraz } \\
\text { inwestycyjnego, przyspieszenie tempa wzrostu produktywności. }\end{array}$ \\
\hline
\end{tabular}

Źródło: opracowanie własne.

Głównym czynnikiem determinującym zakres korzyści związanych z rozwojem Internetu, które zostały omówione w tabeli 3., jest szybkość i zakres jego proliferacji. Porównując dynamikę dyfuzji Internetu oraz innych technologii teleinformatycznych do wcześniejszych technologii ogólnego zastosowania, należy podkreślić rosnące tempo, w jakim pojawiają się kolejne innowacje oraz zwiększenie dynamiki rozwoju ich biznesowych zastosowań, dla których w niespotykanym wcześniej tempie budowane są masowe rynki. Przykładowo w przypadku Stanów Zjednoczonych zelektryfikowanie 1/4 gospodarstw domowych zajęło 46 lat, na osiagnnięcie analogicznej saturacji w przypadku telefonii stacjonarnej potrzebowano 35 lat, a w przypadku samochodów aż 55 lat. Tymczasem komputer osobisty stał się własnością $1 / 4$ gospodarstw domowych już po 16 latach, telefon komórkowy po 13 latach, natomiast Internet przekroczył ten poziom już po 7 latach (Cox, Alm, 1996, s. 9-10). Tą niezwykłą szybkość dyfuzji Internetu w zasadzie we wszystkich gospodarkach wysoko rozwiniętych potwierdzają wykresy 1,2 i 3 . 


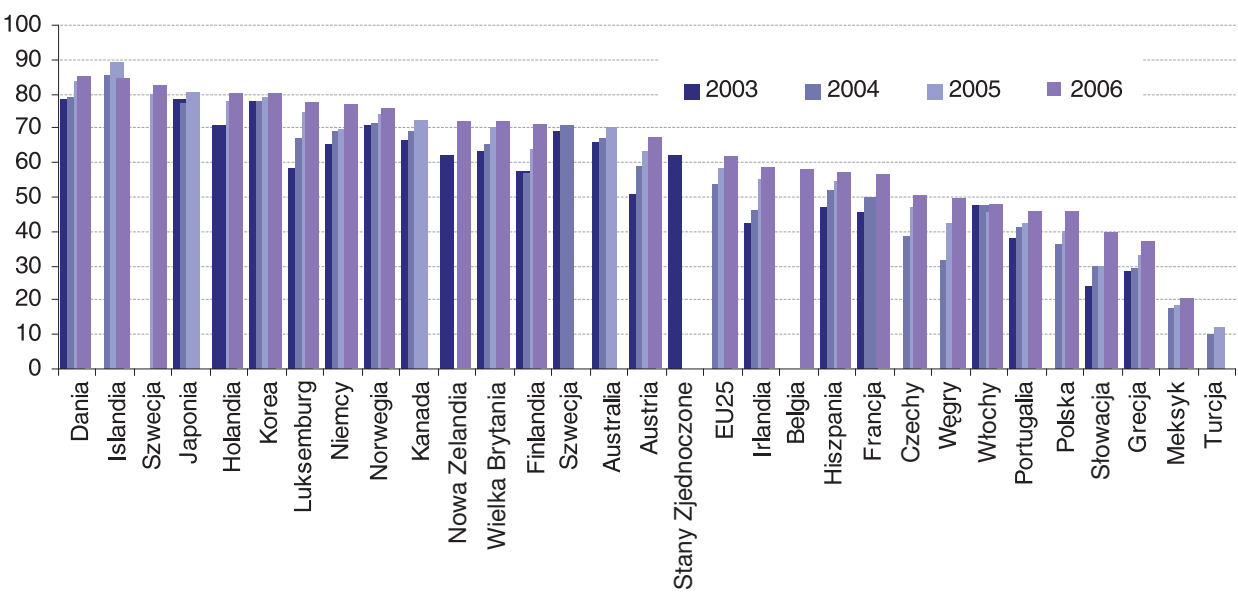

Wykres 1. Procent gospodarstw domowych posiadających komputer w latach 2003-2006 Źródło: OECD, ICT database and Eurostat, Community Survey on ICT usage in households and by individuals, April 2007.

http://www.oecd.org/document/ (data dostępu: 11.12.2007)

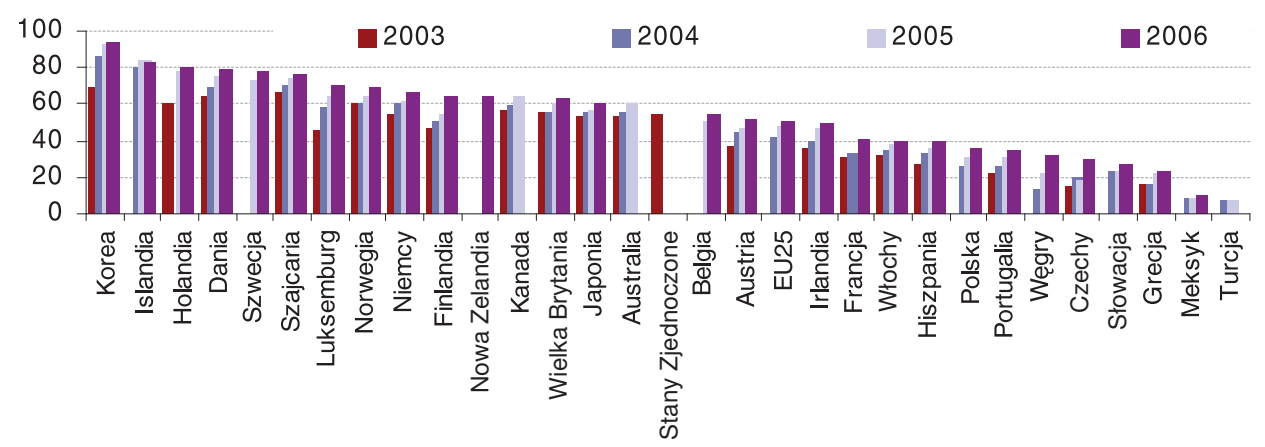

Wykres 2. Procent gospodarstw domowych posiadających dostęp do Internetu w latach 2003-2006

Źródło: OECD and Eurostat, Community Survey on ICT usage in households and by individuals, April 2007.

http://www.oecd.org/document/ (data dostępu: 11.12.2007r.)

Obecnie dominuje pogląd, że warunkiem brzegowym uzyskania pozytywnych efektów z rozwoju technologii ogólnego zastosowania jest jej proliferacja na poziomie $25 \%$ całej zbiorowości. Analiza ekonomicznych konsekwencji rozwoju wcześniejszych technologii ogólnego zastosowania pozwala przyjąć takie kryterium jako poziom gwarantujący istotny wpływ innowacji na cała gospodarkę (Jentzsch, 2001, s. 13). Jak wynika z wykresu 1 przedstawiającego procentowy udział gospodarstw domowych posiadających komputer oraz wykresu 2. 
prezentującego dostęp do Internetu, tylko dwa spośród krajów OECD, Meksyk i Turcja, nie spełniają tego kryterium. Co więcej, większość z analizowanych rozwiniętych gospodarek spełnia już nawet kryterium proliferacji komputerów i Internetu na poziomie $50 \%$, a kraje słabiej rozwinięte gospodarczo redukują lukę technologiczną w tym zakresie w bardzo szybkim tempie.

Analiza danych prezentowanych na wykresie 3. wskazuje na jeszcze wyższy poziom proliferacji Internetu wśród przedsiębiorstw. Na tej podstawie można wysnuć wniosek, że sieć stała się obecnie elementem infrastruktury biznesowej w zasadzie każdego podmiotu gospodarczego. Niemal we wszystkich krajach OECD w 2006 roku nawet w przypadku najmniejszych przedsiębiorstw, dla których są gromadzone dane, poziom proliferacji Internetu przekroczył 90\%, wyjątek w tym zakresie stanowią Węgry i Portugalia $\mathrm{z}$ analizowanym wskaźnikiem na poziomie $77,3 \%$ oraz $80,1 \%$.

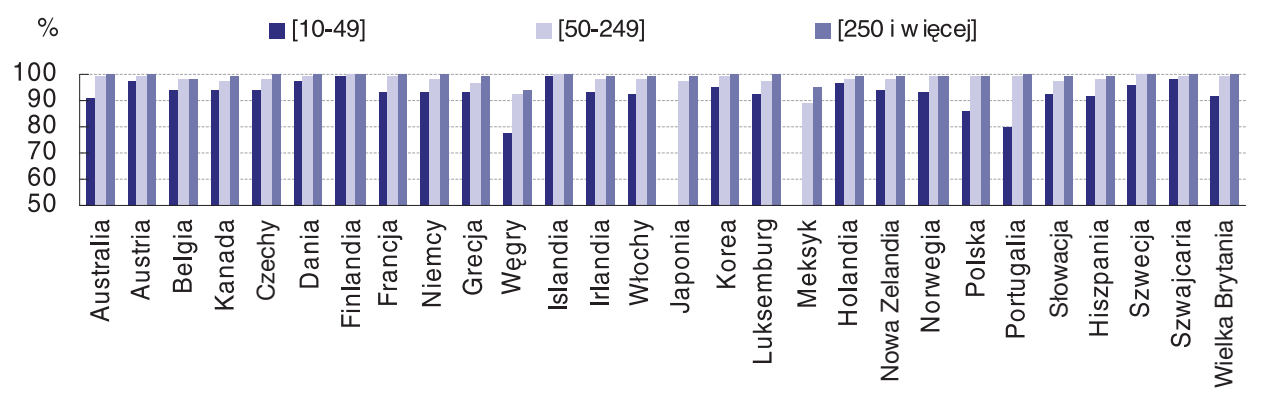

Wykres 3. Saturacja Internetu w firmach zatrudniających co najmniej 10 pracowników w 2006 roku w krajach OECD w \%

Źródło: OECD, ICT database and Eurostat, Community Survey on ICT usage in enterprises, April 2007; http://www.oecd.org/document/ (data dostępu: 11.12.2007)

Rewolucja teleinformatyczna obejmująca rozpowszechnienie się komputera osobistego oraz powstanie Internetu ma ogromny wpływ nie tylko na system organizacyjny przedsiębiorstw, ale także na transformację rynku pracy w sensie jakościowym. Leonard Nakamura podkreśla, że jednym z symptomów fundamentalnej zmiany jakościowej w przypadku gospodarek wysoko rozwiniętych, będącym bardzo silnym argumentem na rzecz tezy o fundamentalnym wpływie technologii teleinformatycznych na transformację gospodarcza, jest ograniczenie czasu ogółu pracowników poświęcanego na bezpośrednią produkcję dóbr i usług. Przykładowo w Stanach Zjednoczonych w 1900 roku pracownicy produkcyjni w sektorze produktów przemysłowych i usług stanowili $82 \%$ całej amerykańskiej siły roboczej. W 1950 roku udział ten obniżył się do 64\% całej siły roboczej. W 1975 roku bezpośrednia produkcja dóbr i usług przestała stanowić 
główne miejsce zatrudnienia większości amerykańskiej siły roboczej, natomiast w 1999 roku już tylko 41\% czasu pracowników było poświęcanych na bezpośrednią produkcję dóbr i usług. Z drugiej strony, udział czasu tzw. pracy kreatywnej (creative work) wykonywanej przez menedżerów i szeroko pojmowanych profesjonalistów wzrósł z 10\% na początku XX wieku do 17\% w 1950 roku i aż do 33\% w 1999. Pozostała część siły roboczej obejmująca sprzedaż i prace administracyjne wzrastały z 8\% w 1990 do 19,5\% i ustabilizowały się od 1970 roku w okolicach 25\%. W 1999 roku udział czasu pracowników zajmujących się sprzedażą i pracą administracyjną wynosiły 26\% (Nakamura, 2000, s. 15-16). Zmiany te mają one charakter uniwersalny, ponadto ich tempo uległo niewątpliwie znacznemu przyspieszeniu w ostatniej dekadzie. Potwierdzaja to dane prezentowane na wykresie 4., gdzie ukazano udział miejsc pracy powiązanych z technologiami teleinformatycznymi w krajach OECD w roku 1995 i 2004.

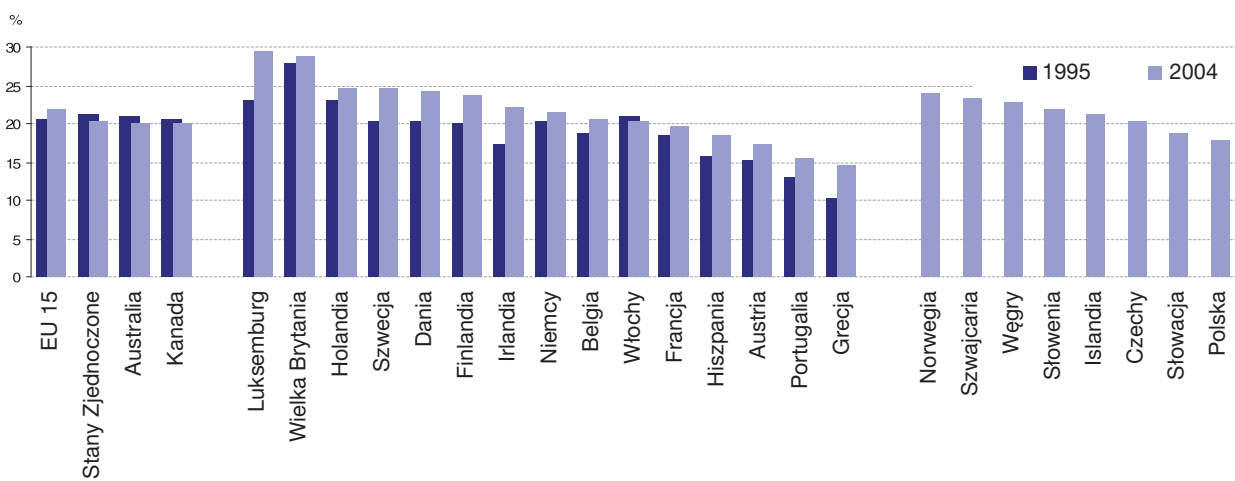

Wykres 4. Udział miejsc pracy powiązanych z technologiami teleinformatycznymi (ICT related jobs) w całej gospodarce według szerokiej definicji w krajach OECD w roku 1995 i $2004^{*}$

* Szeroka definicja miejsc pracy powiązanych z technologiami teleinformatycznymi została przedstawiona w publikacji OECD (2004b) oraz w pracy Desirée van Welsum i Grahama Vickery (2005).

Źródło: EULFS, US Current Population Survey, Statistics Canada, Australian Bureau of Statistics. http://www.oecd.org/document/ (data dostępu: 11.12.2007r.)

\section{TECHNOLOGIE TELEINFORMATYCZNE JAKO AKCELERATOR INNOWACYJNOŚCI GOSPODAREK WYSOKO ROZWINIĘTYCH}

Jednym z najważniejszych kanałów pozytywnego wpływu rozwoju technologii teleinformatycznych jako technologii ogólnego zastosowania jest ich pozytywne oddziaływanie na podnoszenie inowacyjności mikropodmiotów oraz całych gospodarek. Oceniając poziom innowacyjności poszczególnych sfer życia 
gospodarczego na podstawie udziału w ilości przyznawanych patentów, należy stwierdzić, że branża teleinformatyczna stanowi obecnie najbardziej innowacyjną część gospodarki światowej. Ponadto jak wskazują dane z wykresu 5., w ciagu ostatniej dekady, dla której dostępne są dane, jej znaczenie cały czas rosło. O ile w 1991 roku na branżę teleinformatyczną w skali światowej gospodarki przypadało $28,2 \%$ wszystkich przyznanych patentów, o tyle w 2002 roku było to już niemalże 35\%. Natomiast w Finlandii i Korei wskaźnik ten przekroczył 57\%, a w Singapurze wynosił aż $66,3 \%$.

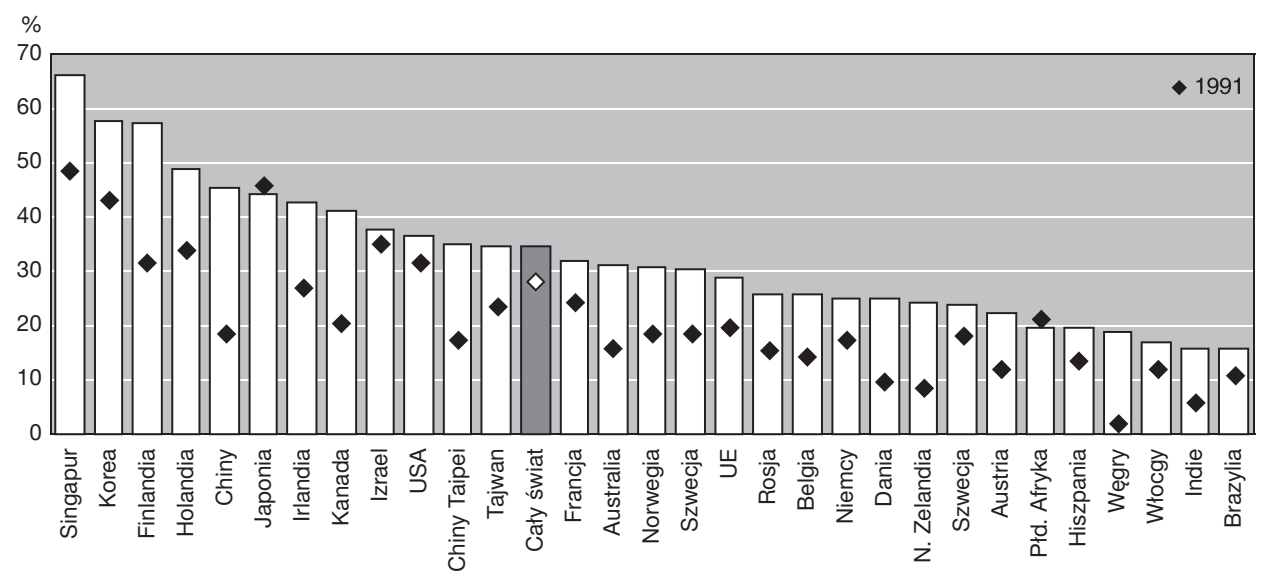

Wykres 5. Udział patentów przyzwanych w branży teleinformatycznej w wszystkich patentach (EPO) w wybranych krajach w roku 1991 i 2002*

* Na wykresie zaprezentowano kraje/gospodarki z ilością aplikacji EPO przekraczającą $100 \mathrm{w}$ roku 2002.

Żródło: OECD, Patent Database, December 2005.

http://www.oecd.org/topicstatsportal/ (data dostępu: 15.12.2007)

Ponadto należy podkreślić, że rozwój technologii teleinformatycznych, ich koszt oraz tempo ich dyfuzji uległo znacznemu przyspieszeniu w drugiej połowie lat dziewięćdziesiątych zeszłego wieku (Jorgenson, Stiroh 1999, s. 109-115). Pojawiła się zupełnie nowa fala innowacji teleinformatycznych budowanych na infrastrukturze Internetowej, umożliwiających rozwój usług charakteryzujących się bardzo wysokimi wymaganiami w zakresie mocy obliczeniowej i przepustowości łącz, jak np. rozwiązania teleinformatyczne gwarantujące symultaniczną transmisję danych, głosu oraz obrazu przy bardzo niskich cenach. Przykładowo koszt międzynarodowej trzyminutowej rozmowy z Nowego Yorku do Londynu w cenach stałych z 2005 roku spadł z 80 \$ w 1950 roku do 0,23 \$ w 2007 roku (OECD 2007, s. 187). Innowacje te przełożyły się istotną zmianę potencjału oraz elastyczności współczesnej infrastruktury telekomunikacyjnej, eliminując ograniczenia oraz minimalizując koszty związane z wcześniejszymi technologiami 
komunikacyjnymi. Te tendencje nie uległy odwróceniu nawet po ogólnoświatowym pęknięciu finansowego bąbla spekulacyjnego w branży teleinformatycznej z roku 2000/2001 (Atkinson, 2005, s. 6-12).

Główną makroekonomiczną konsekwencją tego jest wzrost popytu na sprzęt i usługi teleinformatyczne oraz zwiększenie inwestycji o charakterze teleinformatycznym, co przełożyło się na rozwój branż teleinformatycznych i zwiększenie ich udziału w PKB poszczególnych krajów oraz w wielu przypadkach miało pozytywny wpływ na produktywność. Na wykresie 6. przedstawiono procentowy udział inwestycji w technologie teleinformatyczne w PKB w krajach OECD w latach 1985-2004. Porównując dane z 1985 roku i 2004 roku w większości przypadków można mówić o ich silnym wzroście. W Australii, Finlandii, Wielkiej Brytanii, czy też Grecji nastąpiło wręcz podwojenie udziału inwestycji teleinformatycznych w PKB. Wyjątek w tym zakresie stanowiły Belgia, Norwegia, Portugalia i Irlandia, gdzie wystapił ich spadek.

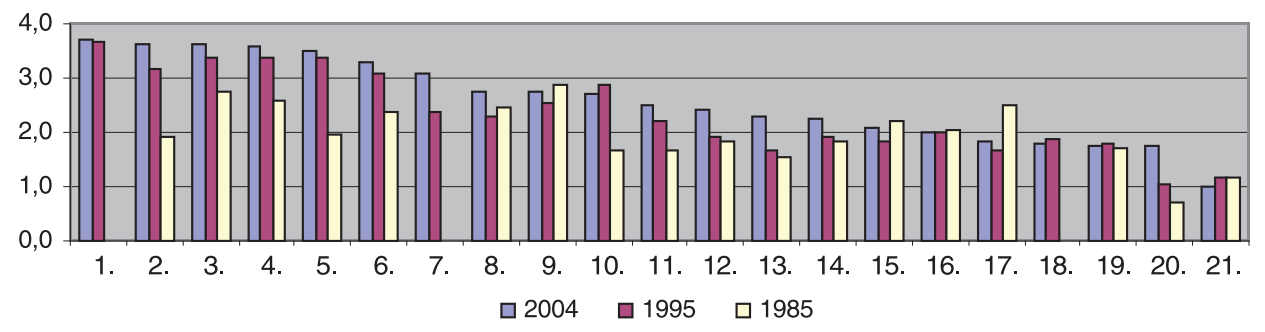

Wykres 6. Procentowy udział inwestycji w technologie teleinformatyczne w PKB w krajach OECD w latach 1985, 1995, 2004

1) Korea; 2) Australia; 3) USA; 4) Szwecja; 5) Finlandia; 6) Dania; 7) Japonia; 8) Nowa Zelandia;

9) Belgia; 10) Wielka Brytania; 11) Kanada; 12) Holandia; 13) Francja; 14) Austria; 15) Norwegia;

16) Hiszpania; 17) Portugalia; 18) Niemcy; 19) Włochy; 20) Grecja; 21) Irlandia.

Rok 1985 - dla Korei, Niemiec, Japonii - brak danych

Rok 2004 - dla Austrii, Belgii, Danii, Finlandii, Grecji, Irlandii, Nowej Zelandii, Holandii, Portugalii, Szwecji, Wielkiej Brytanii, Norwegii - dane dla roku 2003. Dla Nowej Zelandii dane dla roku 2002.

Źródło: OECD Productivity database, April, 5, 2007

http://www.oecd.org/topicstatsportal/ (data dostępu: 15.12.2007)

Analogicznie na wykresie 7. przedstawiono udział inwestycji w technologie teleinformatyczne w akumulacji kapitału trwałego brutto. Także w tym wypadku potwierdza się uniwersalność zjawiska wzrostu ekonomicznego znaczenia technologii teleinformatycznych. W USA i Szwecji udział nakładów na technologie teleinformatyczne w akumulacji kapitału trwałego brutto od 1985 r. uległ podwojeniu i osiągnął niemalże 30\%. W Finlandii wskaźnik ten od 1985 roku wzrósł niemal trzykrotnie osiagając 27\%. W Wielkiej Brytanii, Australii, Nowej 
Zelandii, Danii, Kanadzie i Holandii analizowana wartość od roku 1985 wzrosła z około $10 \%$ do około $20 \%$. Zjawisko to nie wystapiło tylko w Portugalii, gdzie nastapił widoczny spadek udziału inwestycji teleinformatycznych w akumulacji kapitału brutto, Hiszpanii i Irlandii, gdzie można mówić o niewielkim spadku oraz w Belgii, gdzie wystąiła stabilizacja tej wartości na wysokim poziomie $20 \%$.

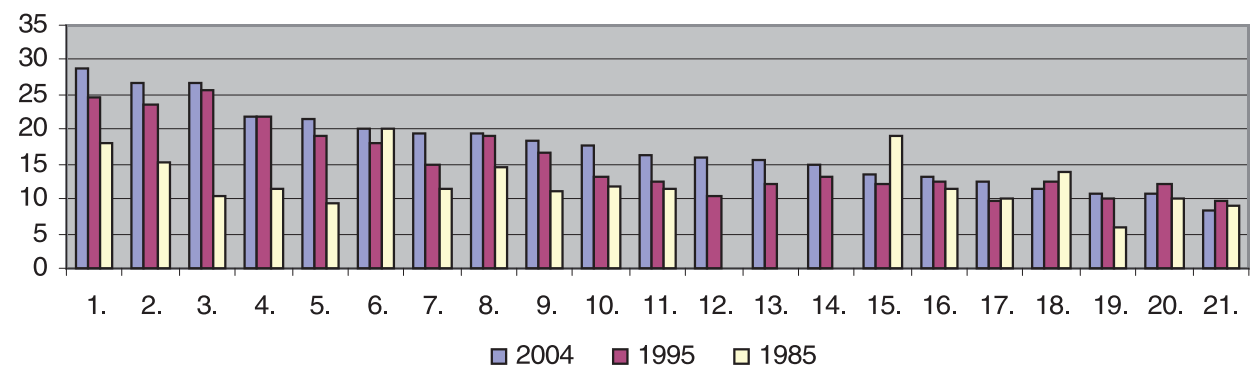

Wykres 7. Procentowy udział inwestycji w technologie teleinformatyczne w akumulacji kapitału trwałego brutto w krajach OECD w latach 1985, 1995, 2004

1) USA; 2) Szwecja; 3) Finlandia; 4) Wielka Brytania; 5) Australia; 6) Belgia; 7) Nowa Zelandia; 8) Dania; 9) Kanada; 10) Holandia; 11) Francja; 12) Japonia; 13) Korea; 14) Niemcy; 15) Portugalia; 16) Austria; 17) Norwegia; 18) Hiszpania; 19) Grecja; 20) Włochy; 21) Irlandia.

Rok 1985 - dla Korei, Niemiec, Japonii - brak danych

Rok 2004 - dla Austrii, Belgii, Danii, Finlandii, Grecji, Irlandii, Holandii, Portugalii, Szwecji, Wielkiej Brytanii - dane dla roku 2003.

Źródło: OECD Productivity database, April, 5, 2007

http://www.oecd.org/topicstatsportal/ (data dostępu: 15.12.2007)

Powyższe dane stanowią niewątpliwie silny argument potwierdzający uniwersalność zjawiska wzrostu makroekonomicznego znaczenia technologii teleinformatycznych.

\section{PODSUMOWANIE}

Podsumowując, dane statystyczne przytoczone w niniejszej pracy stanowia silny argument empiryczny na rzecz tezy o bardzo ważnej roli technologii teleinformatycznych w podnoszeniu efektywności współczesnych wysoko rozwiniętych gospodarek.

Ważnym problemem, jaki należy poruszyć w tym kontekście, jest kwestia ewentualnej roli państwa w tworzeniu warunków dla rozwoju tych technologii oraz wykorzystania ich potencjału przez większość sektorów danej gospodarki. $\mathrm{Z}$ omówionych w niniejszej pracy wynika, że głównym zadaniem rządu w tym zakresie jest zwiększanie zdolności gospodarki do dostosowywania się do szybkich 
zmian technologicznych. Ta wysoka technologiczna elastyczność gospodarki jest uzależniona od wystarczającej dostępności wysokiej jakości kapitału ludzkiego, niskich kosztów transakcyjnych reengineeringu organizacyjnego przedsiębiorstw, dobrze funkcjonujących rynków finansowych oraz rynków produktów, które charakteryzują się wysoką presją konkurencyjną wymuszającą na mikropodmiotach poszukiwanie nowych rozwiązań organizacyjnych i technologicznych. Wszystkie te elementy przekładają się na jakość otoczenia biznesowego, które dzięki temu może sprzyjać proliferacji oraz dobremu wykorzystaniu potencjału nowych technologii, podnosząc innowacyjność poszczególnych przedsiębiorstw, całych branż oraz gospodarki w sensie globalnym.

\section{LITERATURA}

Atkinson R. D. (2005), The Post and Future of America's Economy. Long Waves of Innovation that Power Cycles of Growth, Edward Elgar, Washington 2005.

Barber B. M., Ocean T. (2001), The Internet and the Investor, „Journal of Economic Perspectives", Vol. 15, No. 1.

Black S. E., Lynch L. M. (2004), What's Driving the New Economy?: The Benefits of Workforce Innovation, „Economic Journal”, Vol. 114, No. 493.

Black S. E., Lynch L. M. (2001), How to Compete: The Impact of Workplace Practices and Information Technology on Productivity, ,Review of Economics and Statistics”, Vol. 83, No. 3.

Bloom N, Sadun R., Van Reenen J. (2007), Americans Do I.T. Better: US Multinationals and the Productivity Miracle, NBER Working Paper Series, Working Paper, No. 13085, May.

Borenstein S., Saloner G. (2001), Economics and Electronic Commerce, „Journal of Economic Perspectives", Vol. 15, No. 1.

Bresnahan T. F., Brynjolfsson E., Hitt L. M. (2002), Information Technology, Workplace Organization, and the Demand for Skilled Labor: Firm-Level evidence, „Quarterly Journal of Economics", No 1.

Bresnahan T. F., Trajtenberg M. (1995), General Purpose Technologies „Engines of Growth”?, „Journal of Econometrics”, Vol. 65, No 1.

Brynjolfsson E., Hitt L. M. (2003), Computing Productivity: Firm-Level Evidence, „Review of Economics and Statistics”, Vol. 85, No. 4.

Carlsson B. (2004), The Digital Economy: What is New and What is Not?, „Structural Change and Economic Dynamics", Vol. 15, No. 3.

Cette G., Maiuresse J., Kcoglu Y. (2004), ICT Diffusion and Potential Output Growth, Notes D'Etudes Et De Recherche, NER 112, Banque de France, Direction Generale Des Etudes ET Des Relations Internationales.

Cox M. W., Alm R. (1996), The Economy at Light Speed: Technology and Growth in the Information Age - and Beyond, Federal Reserve Bank of Dallas 1996 Annual Report. 
Daveri F. (2003), Information Technology and Productivity Growth Across Countries and Sectors, [w:] D. C. James (red.), New Economy Handbook, Elsevier Academic Press, San Diego.

Eliasson G., Johansson D., Tayma E. (2004), Simulating the New Economy, „Structural Change and Economic Dynamics", Vol. 15.

Engelbrecht H. J. (2005), ICT Research, the New Economy, and the Evolving Discipline of Economics: Back to the Future?, „Information Society”, Vol. 21.

EULFS [2007], US Current Population Survey, Statistics Canada, Australian Bureau of Statistics. http://www.oecd.org/document/ (data dostępu: 11.12.2007r.).

Freund C., Weinhold D. (2002), The Internet and International Trade in Services, „American Economic Review”, Vol. 92, No. 2.

Gera S., Gu W., Lee F. C. (1999), Information Technology and Labor Productivity Growth : An Empirical Analysis for Canada and United States, „Canadian Journal of Economics", Vol. 32, No. 2.

Jentzsch N. (2001), The New Economy Debate in the U.S.: A Review of Literature, Freie Universitat Berlin, John F. Kennedy Institute for North American Studies, Section of Economics, Working Paper No. 125, April.

Jorgenson D. W., Stiroh K. J. (1999), Information Technology and Growth, „American Economic Review", Vol. 89, No. 2.

Kołodko G. W. (2001), „Nowa gospodarka” i stare problemy. Perspektywy szybkiego wzrostu w krajach posocjalistycznej transformacji, [w:] G. W. Kołodko (red.), „Nowa gospodarka” i jej implikacje dla dtugookresowego wzrostu w krajach posocjalistycznych, Wydawnictwo Wyższej Szkoły Przedsiębiorczości i Zarządzania im. Leona Koźmińskiego, Warszawa.

Litan R. E., Rivlin A. (2001), Projecting Economic Impact of the Internet, „American Economic Review", Vol. 91, No. 2.

Lucking-Reiley D., Spulber D. F. (2001), Business-to-Business Electronic Commerce, „Journal of Economic Perspectives”, Vol. 15, No. 1.

Nakamura L. I. (2000), Economics and the New Economy: The Invisible Hand Meets Creative Destruction, „Federal Reserve Bank of Philadelphia Business Review”, July/August.

OECD (2007), ICT database and Eurostat, Community Survey on ICT usage in households and by individuals, April 2007. http://www.oecd.org/document/ (data dostępu: 11.12.2007).

OECD (2007), Productivity database, April, 5, 2007 http://www.oecd.org/topicstatsportal (data dostępu: 15.12.2007).

OECD (2007), OECD Economic Outlook, Vol. 2007, Issue 1, No. 81.

OECD, Patent Database, December 2005. http://www.oecd.org/topicstatsportal/ (data dostępu: 15.12.2007).

OECD (2004a), The Economic Impact of ICT, Measurement, Evidence and Implications, OECD, Paris.

OECD (2004b), Information Technology Outlook 2004, OECD, Paris.

Salvatore D. (2003), The New Economy and Growth in the G-7 Countries, „Journal of Policy Modeling”, Vol. 25. 
Wilhelm W. J. (2001), The Internet and Financial Market Structure, „Oxford Review of Economic Policy", Vol. 17, No. 2.

Williamson O. (2000), The New Institutional Economics: Taking Stock, Looking Ahead, „Journal of Economic Literature”, Vol. 38, September.

Van Welsum D., Vickery G. (2005), New Perspectives on ICT Skills and Employment, DSTI Information Economy Working Paper, DSTI/ICCP/IE(2004)10/FINAL, OECD, Paris.

Van Ark B., Inklaar R., McGucking R. H. (2003), The Contribution of ICT-Producing and ICT-Using Industries to Productivity Growth: A Comparison of Canada, Europe and the United States, „International Productivity Monitor”, No. 6, Spring.

\section{THE ROLE OF INFORMATION TECHNOLOGIES IN IMPROVING MICRO AND MACROECONOMIC EFFECTIVENESS OF ECONOMY}

Abstract. The article concentrates on the influence of information technology proliferation on effectiveness of economy from the micro and macroeconomic perspective. The aim of the paper is to discuss the conditions that must be fulfilled in order to utilize the potential of information technologies as much as its possible.

K e y w ord s: innovativeness, information-communication technologies, Internet, general purpose technology. 